\title{
Effect of BCG-vaccination upon the Multiplication of Mycobacterium leprae in the Foot-pads of Mice
}

\author{
Michiaki MAEDA and KazUnari NAKAMURA \\ (National Institute for Leprosy Research) \\ HiRoo KATAYAMA \\ (Tokyo Medical and Dental University)
}

The transmission of $M$. leprae into the foot-pads of mice met with success in our laboratory since 1965, and the effect of BCG-vaccination upon the multiplication of $M$. leprae was studied in the foot-pads of mice.

BCG was injected subcutaneously, intramuscularly, intraperitoneally and intravenously with the suspension in saline solution or with mixture in Adjuvant. 4 strains of $M$. leprae used for the infection of leprosy were injected subcutaneously into the footpads of mice.

The results obtained were as follows:

1) Living or heat-killed BCG with imcomplete Adjuvant were injected intramuscularly into mice, and $M$. leprae was injected at one month after the vaccination or after the infection of leprosy. In these experiments, the effect of BCG-vaccination was found in one case, but this could not be seen in the other cases.

2) The vaccination of BCG into mice was more effective on the subcutaneous injection into the foot-pads or the intravenous injection than on the intramuscular or intraperitoneal injection.

3) The effect of vaccination with BCG mixtured in Adjuvant was more remarkable than that with the suspension of BCG in saline solution.

4) BCG-vaccination was most effective from one month before the infection to one month after the infection.

If the experiment in mice was tried under the condition described above, it was indicated that BCG-vaccination was effective upon the multiplication of $M$. leprae in the foot-pads of mice. This result obtained in animal experiment might be equal to the effect of BCG-vaccination obtained in the epidemiological investigation, as reported already by several researchers. Therefore, $B C G$-vaccination was effective upon the protection against leprosy. 


\title{
マウス足底部での M. leprae 増殖 に対する B C G 接種の影響
}

\author{
前田道 明・中村一成 \\ (国立多摩研究所) \\ 片山博 雄 \\ (東京医科囦科大学) \\ （浸付 1967年12月28日）
}

B C G接種が一般住民に拈けるらいの予防に有効であ るか否か、関しては従来諸家の報告があるが，らいの発 病には M. leprae による感染以外に諸因子が加味され るため, 被検対象の発病率存検討する疫学的調查成績か らその效果を確実に結論ずけうる段階には至っていな u。

従来らい感染に関する動物実験は成功していなかった ために, BCGの予防效果化関す石基碟的研究は不可能 であったが，1960年 Shepard がマウス足底部における M. leprae の移植累代に成功1，2してからは，てれを検 討する緒口を見出しえたと言うことが出来よう。われわ れの研究室で毛1964年以来マウスへの M. leprae 移植に 関する研究を続け，その成果については 1965 年以後報 告してきた ${ }^{3 \sim 6)}$ 。動物移植の研究之併行してわれわれ は，日本の患者から分離した M. leprae を用いてマウ ス足底部での M. leprae の発育に対する BCG 接種の 影響について検討を加えたので，その成果について報告 する。

\section{実 験 方 法}

免疫に使用したBCGは, 日本BCG研究所より分与 をうけた凍結乾燥 B C G およびこれを Sauton 培地で増 殖させたすのである。免疫時には生菌のままか或は加熱 死菌安生食水浮遊液或は Adjuvant 加浮遊液として用い た。BC G接種はマウスの左下肢大煺部の筋肉内，足荿 部皮下, 腹腔内或は尾静脈内注射によって行なった。

感染に用いた M. leprae は，われわれが日本のらい 腎者より分離した藤开株，鈴木株，浦島株および米国 Shepard 博士上り分与をうけた S H株であった。これら の M. leprae はいずれ屯マウス足底部で累代されてい るあのである。らいの感染はマウス足瓜部への皮下注射
によって行なわれ，その免疫効果はマウス足战部組織内 の菌数の多萓によって判定した。また菌数の計算はさき に報告した乳棒法6)によって行なった。

\section{実 験 成 績}

\section{1) マウス筋肉内 B C G 接種}

a) 奏験 1 : B C G生菌或は加熱死菌を不完全 Adjuvant と共にマウス左下肢の大腿部筋肉内人注射し, B C G 接種 後 1 力月目に M. leprae 鈴木株或は藤井株を 右足底部皮下へ注射して感染した。B C G 接種生菌数 は $5 \times 10^{5}$ コ/マウスであり, 感染 M. leprae の菌数は 画菌株いすずれとす $5 \times 10^{4}$ コ/マウスであった。

感染後 5 力月目に打右足低部組織内の平均菌数 は，表1亿示す通りである。非免疫マウスに拈る菌数 の指数と免疫マウスにおける菌数の指数との差を求めて 両群比較すると， B C G 生菌免疫の場合も死菌免疫の 場合之同じく指数は 1 以下であった。従って，BC Gの 生菌・死菌間に打ける免疫効果に差は認めら扎或, BC Gの M. leprae 増殖に 対する抑制効果は明らかではな 加った。

b ）奏験 II：B C G生菌或は加熱死菌0.1mgずつを不 完全 Adjuvant 己共にマウス左下肢の大腿部笳肉内一 注射し， BCG接種後 1 力月目K M. leprae 浦島株を 在足䣌部皮下へ注射し感染した。接種された BCGの生 菌数は $1 \times 10^{6}$ コ/マウスであり，感染した M. leprae の菌数は $1 \times 10^{5}$ コ/マウスであった。

感染後 $7 \sim 10$ 力月目に抄ける右足成部組織内の平均菌 数は，表 2 に示す通りである。足底部におけるM. leprae の堌殖抑制効果免疫マウスに打ける菌数の指数と非免 疫マウスにおける菌数つ指数上の差によって表現する 亡, 感染後 $7,8,9$ 力月目沉打ける指数の差は $\mathrm{BC} \mathrm{G}$ 
Table 1. Effect of BCG in Mice Vaccinated Intramuscularly (Experiment I)

\begin{tabular}{|c|c|c|c|c|}
\hline $\begin{array}{l}\text { M. Jeprae } \\
\text { challenged }\end{array}$ & Group of mice & $\begin{array}{l}\text { No. of } \\
\text { mice }\end{array}$ & $\begin{array}{l}\text { Bacillary count } \\
\text { in average }\end{array}$ & Difference (Log.) \\
\hline \multirow{3}{*}{ Suzuki-strain } & $\begin{array}{l}\text { Vaccinated with } \\
\text { living } B C G\end{array}$ & 3 & $42.75 \times 10^{4}$ & 0.57 \\
\hline & $\begin{array}{l}\text { Vaccinated with } \\
\text { killed BCG }\end{array}$ & 3 & $15.54 \times 10^{4}$ & 1.01 \\
\hline & Non-vaccinated & 2 & $15.82 \times 10^{5}$ & 0 \\
\hline \multirow{3}{*}{ Fujii-strain } & $\begin{array}{l}\text { Vaccinated with } \\
\text { living } B C G\end{array}$ & 4 & 45. $76 \times 10^{5}$ & 0.24 \\
\hline & $\begin{array}{l}\text { Vaccinated with } \\
\text { killed BCG }\end{array}$ & 4 & $29.73 \times 10^{5}$ & 0.42 \\
\hline & Non-vaccinated & 2 & $79.06 \times 10^{5}$ & 0 \\
\hline
\end{tabular}

Table 2. Effect of BCG in Mice Vaccinated Intramuscularly (Experiment II)

\begin{tabular}{|c|c|c|c|c|}
\hline $\begin{array}{l}\text { Time of } \\
\text { autopsy }\end{array}$ & Group of mice & $\begin{array}{l}\text { No. of } \\
\text { mice }\end{array}$ & $\begin{array}{l}\text { Bacillary count } \\
\text { in average }\end{array}$ & Difference (Log.) \\
\hline \multirow{3}{*}{$\begin{array}{c}7 \\
\text { month }\end{array}$} & $\begin{array}{l}\text { Vaccinated with } \\
\text { living } B C G\end{array}$ & 4 & $3.34 \times 10^{4}$ & 0.82 \\
\hline & $\begin{array}{l}\text { Vaccinated with } \\
\text { killed BCG }\end{array}$ & 4 & $18.52 \times 10^{4}$ & 0.08 \\
\hline & Non-vaccinated & 4 & $22.00 \times 10^{4}$ & 0 \\
\hline \multirow{3}{*}{$\begin{array}{c}8 \\
\text { month }\end{array}$} & $\begin{array}{l}\text { Vaccinated with } \\
\text { living } B C G\end{array}$ & 4 & $2.74 \times 10^{4}$ & 1.08 \\
\hline & $\begin{array}{l}\text { Vaccinated with } \\
\text { killed BCG }\end{array}$ & 4 & $22.00 \times 10^{4}$ & 0.17 \\
\hline & Non-vaccinated & 4 & $32.90 \times 10^{4}$ & 0 \\
\hline \multirow{3}{*}{$\begin{array}{c}9 \\
\text { month }\end{array}$} & $\begin{array}{l}\text { Vaccinated with } \\
\text { living } B C G\end{array}$ & 3 & $3.42 \times 10^{4}$ & 1.04 \\
\hline & $\begin{array}{l}\text { Vaccinated with } \\
\text { killed BCG }\end{array}$ & 4 & $25.49 \times 10^{4}$ & 0.17 \\
\hline & Non-vaccinated & 4 & $37.38 \times 10^{4}$ & 0 \\
\hline
\end{tabular}

生菌免疫群では0.8〜1.1であったのに対し B C G 死菌免 疫群では0.1〜0.2kすぎなかった。この実験では，BC G生菌による免疫ではらい発病に対する防禦能は僅かな がら認められたが，BC G死菌による兔疫ではその防禦 能は認められなかった。

c）実験III：M. leprae 鈴木株をマウス右足疷部皮下 へ注射して感染し, 感染と同時或は感染後 $1,2,3$ 力 月目に感染マウスの左下肢大腿部笳肉内へ B C G 生菌 0.5mgずつを注射した。免疫に用いたB C Gの接種生菌
数はそれぞれ $8 \times 10^{6} \sim 4 \times 10^{7}$ コ/マウスであり，感染 に用いた M. leprae の菌数は $2 \times 10^{4}$ コ/マウスであっ t。

感染後 5 力月および 6.5 力月目における右足底部組織 内の平均菌数は, 表 3 に示主通りである。各免疫マウス 群における菌数の指数と非免疫マウスにおける菌数の指 数との差によって菌增殖抑制能を比較すると, 感染後 5 力月目における成績ではらい感染後 2 および 3 力月目に B C G 接種した場合の方力感染後 1 力月以内にBCG 
Table 3. Effect of BCG in Mice Vaccinated Intramuscularly (Experiment III)

\begin{tabular}{|c|c|c|c|c|}
\hline $\begin{array}{l}\text { Time of } \\
\text { autopsy }\end{array}$ & Time of vaccination & $\begin{array}{l}\text { No. of } \\
\text { mice }\end{array}$ & $\begin{array}{l}\text { Bacillary count } \\
\text { in average }\end{array}$ & Difference (Log.) \\
\hline \multirow{5}{*}{$\begin{array}{c}5 \\
\text { month }\end{array}$} & $\begin{array}{l}\text { at same time as } \\
\text { challenge }\end{array}$ & 3 & $3.97 \times 10^{4}$ & \multirow{5}{*}{$\begin{array}{l}0.46 \\
\text { more than } 1.00 \\
\text { more than } 1.00 \\
0\end{array}$} \\
\hline & $\begin{array}{l}1 \text { month after } \\
\text { challenge }\end{array}$ & 3 & $3.61 \times 10^{4}$ & \\
\hline & $\begin{array}{l}2 \text { months after } \\
\text { challenge }\end{array}$ & 3 & less than $10^{4}$ & \\
\hline & $\begin{array}{l}3 \text { months after } \\
\text { challenge }\end{array}$ & 3 & less than $10^{4}$ & \\
\hline & Non-vaccinated & 3 & 10. $40 \times 10^{4}$ & \\
\hline \multirow{5}{*}{$\begin{array}{c}6.5 \\
\text { month }\end{array}$} & $\begin{array}{l}\text { at same time as } \\
\text { challenge }\end{array}$ & 4 & $40.56 \times 10^{4}$ & 0.09 \\
\hline & $\begin{array}{l}1 \text { month after } \\
\text { challenge }\end{array}$ & 3 & $58.40 \times 10^{4}$ & -0.07 \\
\hline & $\begin{array}{l}2 \text { months after } \\
\text { challenge }\end{array}$ & 3 & 91. $48 \times 10^{4}$ & -0.26 \\
\hline & $\begin{array}{l}3 \text { months after } \\
\text { challenge }\end{array}$ & 3 & $136.90 \times 10^{4}$ & -0.44 \\
\hline & Non-Vaccinated & 3 & $50.00 \times 10^{4}$ & 0 \\
\hline
\end{tabular}

接種を行なった場合よりも M. leprae の増殖を抑制し ていた。しかし，感染後 6.5 力月目における成績では， らい感染後 1 力乃以内に B C G免疫をうけたマウス群で は非免疫マウス群とほほ同じ菌数を示しているのに，ら い感染後 2 或は 3 力月目にBCG接種をうけたマウスで はBC.G非接種マウスより菌数が多くなっている傾问 がみられた。

B C G 生菌を筋肉内へ注射して免疫した場合のこれら の成績加ら，BCG危疫の効果煘染したM. leprae の 足底部組織内における菌数の差からみると， B C G 接種

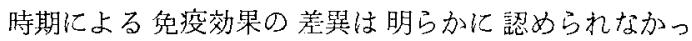
た。

\section{2) B C G接種方法に対する検討}

マウスでの実験的結核症に执いてBCGの效果を検討 する場合には，BC Gの接種方法が問題となる。上述の $\mathrm{BCG}$ 生菌或は死菌をマウス筋肉内に接種した場合の兔 疫効果老比較してみると，B C Gの投与晆期には関係な く，明確な成績が得られなかったのは，B C Gの投与方 法に問題があるためと考えられた。そこでBC G生菌の 投与方法を次の 4 群にわけて検討を加えた。

i ) $\mathrm{BCG}$ 生菌腹陀内へ注射した後 24 日目に $\mathrm{M}$. leprae で感染した群（BC G生菌腹腔群）

ii） B C G生菌青静脈内人注射した後 29 日目K M. leprae で感染した群（BCG生菌静注群）

iii） BCG生菌を左足底部皮下八注射した後51月目に M. leprae で感染した群 ( B C G 生菌是底群)

iv) Drackeol No.6 Adjuvant としたBCG生菌它 左足底部皮下八注射した後 51 日目に M. leprae で感 染した群 (Adjuvant 加 BCG 生菌足底群)

使用した B C Gの接種生菌数は各マウス当り $2.0 \times 10^{7}$ 〜 4. $0 \times 10^{6}$ コであり，また感染に用いた M. Jeprae 米 国株は右足成部皮下八注射され，その菌数は $8.0 \times 10^{4}$ コ/マウスであった。

感染後 5 力月目に括ける各群のマウス足底部組織内の 菌数は，表4汇示す通りである。 $\mathrm{B} \mathrm{C} \mathrm{G}$ 生菌腹腔群は非 免疫群と大差のない菌数であり，B G 生菌の腹腔内注 射によってはマウスの免疫效果は珰められない上考えら れた。しかし，BCG生菌静注群执よびBC G生菌足底 群では非免疫群よりあ菌数が少く, 特に後者の免疫マウ スでは非免疫群との差か顕著であった。さらに Adjuvant 加 $\mathrm{BCG}$ 生菌足底群です非免疫群上り菌数が少 く，明らかにB C Gの免疫効果が諗められた。

これらの成績から，BC G生菌のマウスに対する免疫 附与力法としては，足咸部皮下注射法か或は静脈内注射 法が極めて有效であることを知りえた。

3）マウス足底部皮下 BCG接種 
Table 4. Investigation on Method of BCG-administration

\begin{tabular}{|c|c|c|c|c|c|}
\hline $\begin{array}{l}\text { Kind of } \\
\text { BCG }\end{array}$ & $\begin{array}{l}\text { Method of } \\
\text { administration }\end{array}$ & $\begin{array}{l}\text { Period after } \\
\text { vaccination }\end{array}$ & $\begin{array}{l}\text { No. of } \\
\text { mice }\end{array}$ & $\begin{array}{l}\text { Bacillary count } \\
\text { in average }\end{array}$ & $\begin{array}{r}\text { Difference } \\
\text { (Log.) }\end{array}$ \\
\hline $\begin{array}{c}\text { Living } \\
\text { BCG }\end{array}$ & intraperitoneal & 24 days & 4 & $33.8 \times 10^{6}$ & -0.40 \\
\hline$" 1$ & intravenous & 29 days & 6 & 4. $26 \times 10^{6}$ & 0.50 \\
\hline$"$ & $\begin{array}{l}\text { subcutaneous in } \\
\text { foot-pad }\end{array}$ & 51 days & 2 & $4.03 \times 10^{5}$ & 1.52 \\
\hline $\begin{array}{c}\begin{array}{c}\text { Living } \mathrm{BCG} \\
\text { with } \\
\text { Drackeol }\end{array} \\
\end{array}$ & $\begin{array}{l}\text { subcutaneous in } \\
\text { foot-pad }\end{array}$ & 51 days & 4 & 1. $17 \times 10^{6}$ & 1.06 \\
\hline \multicolumn{2}{|c|}{ Non-vaccinated } & & 4 & 13. $46 \times 10^{6}$ & 0 \\
\hline
\end{tabular}

B C G 接種はすべてマウスの左側足底部皮下注射によ って行なわれたが，使用したBCGてよって次の 4 群に わけて比較検討した。

i ) B C G 生菌生食水浮遊液接種後35日目にM. leprae で感染した群( BC G生菌群)

ii) $\mathrm{BCG}$ 加熱死菌生食水浮遊液接種後35П目に M. leprae で感染した群（B C G死菌群）

iii) Drackeol No. 6 Adjuvant とした B C G生菌 浮遊液 接種後 27 日目に M. leprae で感染した群 (Adjuvant 加 B C G 生菌群)

iv) Drackeol No. 6 を Adjuvant とした BC G 加熱 死菌浮遊液接㮔徯27日目に M. leprae で感染した群 (Adjuvant 加 $\mathrm{BCG}$ 死菌群)

使用したBCGの接種生菌数は $8.0 \times 10^{6}$ コ/マウスで ありまた右側足底部皮下注射によって感染した $\mathrm{M}$. leprae 米国株の菌数は $1.0 \times 10^{4}$ コ/マウスであった。
感染後 4.5〜 5. 0 力月目拈よび 6. 0 6.5 力月目に括け る各マウス群の足底部組絨内の平均菌数は, 表 5 亿示す 通りである。非免疫群における菌数の指数と兔疫群に沶 ける菌数の指数との差に上って各群間のB C G 接㮔効果 を比較してみると，最屯頙著な効果を示したのは Adjuvant 加 B C G 生菌群であり，次いで B C G生菌群， Adjuvant 加 BCG死菌群の順にいずれ委 M. leprae の 発育在抑制していたが，加熱B C G 死菌群のみは全く効 果龺認めえなかった。

これらの成績から，BCG生菌をらい感染 1 力月前に 接種すると，マウス足底部組織内におけるM. leprae の 発育仙抑制され，且つAdjuvant 加 B C G 生菌接種が最 あ抑制力が大きいことを確認することが出来た。

4) マウス尾静脈内 B C G接種

Shepard より分与された M. leprae (US 株) をマウ スの右足底部皮下へ注射して感染し, 感染と同時扔よび

Table 5. Effect of BCG in Mice Injected Subcutaneously into Foot-pads (Experiment IV)

\begin{tabular}{|c|c|c|c|c|}
\hline \multirow{2}{*}{$\begin{array}{c}\text { Kind of } \\
\text { BCG }\end{array}$} & \multirow{2}{*}{$\begin{array}{l}\text { Period after } \\
\text { vaccination }\end{array}$} & \multirow{2}{*}{$\begin{array}{l}\text { No. of } \\
\text { mice }\end{array}$} & \multicolumn{2}{|c|}{ Bacillary count in average } \\
\hline & & & 4. $2 \sim 5.0$ months & $6.0 \sim 6.5$ months \\
\hline Living $\mathrm{BCG}$ & 35 days & 3 & $4.2 \times 10^{5}(1.30)^{*}$ & $1.5 \times 10^{7}(0.66)^{*}$ \\
\hline Heat-killed BCG & 35 days & 3 & $9.2 \times 10^{6}(-0.05)^{*}$ & $6.9 \times 10^{7}(-0.51)^{*}$ \\
\hline $\begin{array}{l}\text { Living BCG } \\
\text { with Drackeol }\end{array}$ & 27 days & 3 & $\begin{array}{l}\text { less than } 10^{5} \\
\text { (More than } 1.2)^{*}\end{array}$ & $\begin{array}{l}\text { less } \operatorname{than} 10^{5} \\
\text { (More than 2.2)* }\end{array}$ \\
\hline $\begin{array}{l}\text { Heat-killed BCG } \\
\text { with Drackeol }\end{array}$ & 27 days & 3 & $3.7 \times 10^{6}(0.35)^{*}$ & $7.5 \times 10^{6}(0.45)^{*}$ \\
\hline \multicolumn{2}{|c|}{ Non-vaccinated } & 3 & $8.3 \times 10^{6}(0)$ & $2.1 \times 10^{7}(0)$ \\
\hline
\end{tabular}

( )* shows the difference (Log.) 
感染後 $1,2,3$ 力月目に B C G 生菌 $0.25 \mathrm{mg}$ ずつを尾 静脈内へ注射した。免疫に用いた B C Gの接種生菌数は $8 \times 10^{6}$ コ/マウスであり，感染に用いた M. leprae の 菌数は $8.0 \times 10^{4}$ コ/マウスであった。

感染後 4 力月目执よび 5 力月目汇おける右足䇙部組紽 内の平均菌数をしら心゙る之，表 6 亿示す通りである。兔 疫マウスにおける菌数の指数之非免疫マウスにおける菌 数の指数との差を各免疫群間で比較すると，感染後いず れの検查時期に扰ける成績でも感染之同時または感染後 1 力月目に B C G 接種を行なった群の方が感染後 2 或は 3カ月目に BCG 接種を行なった群よりも M. leprae の発育を阻止していることが認められた。従ってBC G 投与恰感染後 1 力月以内に行なうのが最屯有効であると 言えよう。
考察

M. leprae の動物移植が可能でなかった頃は,らい発 病に対するBCGの予防効果について実駼的検討を加㫕 ることが不可能であった。従って，らい発生地域の住民 について疫学的に B C G 接種の既往歴やッベルクリン反 応の成績をしらべ, BC G 接種群に扔けるらい発病率之 非接種群におけるを扎上の比較を行ない，BCGのらい 発病阻止について検討を重ねてきた。現在まで報告さ れている主な成績を要約すると，表 7 に示す如くであ る。柳沢らわがわが国のらい患者接触览童についてらい 発病前のツ反応成績および B C G 接種の有無上らい発病 率との関係を調查した成績によると，ツ反忘既陽性者加 らのらい発病は79名中 4 名 $(5.1 \%)$, ツ反応陰性のため

Table 6. Effect of BCG in Mice Vaccinated Intravenously

\begin{tabular}{|c|c|c|c|c|}
\hline $\begin{array}{l}\text { Time of } \\
\text { autopsy }\end{array}$ & $\begin{array}{l}\text { Time of } \\
\text { vaccination }\end{array}$ & $\begin{array}{l}\text { No. of } \\
\text { mice }\end{array}$ & $\begin{array}{l}\text { Bacillary count } \\
\text { in average }\end{array}$ & Difference (Log.) \\
\hline \multirow{5}{*}{$\begin{array}{c}4 \\
\text { months }\end{array}$} & at same time as challenge & 4 & $3.54 \times 10^{4}$ & 1. 13 \\
\hline & 1 month after challenge & 4 & $1.58 \times 10^{4}$ & 1.48 \\
\hline & 2 months after challenge & 3 & $25.00 \times 10^{4}$ & 0.28 \\
\hline & 3 months after chalienge & 2 & $20.92 \times 10^{4}$ & 0.36 \\
\hline & Non-vaccinated & 4 & 48. $14 \times 10^{4}$ & 0 \\
\hline \multirow{5}{*}{$\begin{array}{l}5 \\
\text { months }\end{array}$} & at same time as challenge & 4 & $15.95 \times 10^{5}$ & 0.86 \\
\hline & 1 month after challenge & 7 & $20.39 \times 10^{5}$ & 0.75 \\
\hline & 2 months after challenge & 6 & $41.56 \times 10^{5}$ & 0.44 \\
\hline & 3 months after challenge & 5 & $125.9 \times 10^{5}$ & -0.04 \\
\hline & Non-vaccinated & 6 & $114.7 \times 10^{5}$ & 0 \\
\hline
\end{tabular}

Table 7. Effect of BCG-vaccination upon the Outbreak of Leprosy among Inhabitants

\begin{tabular}{l|r|r|r|r}
\hline \multicolumn{1}{c|}{ Reporter } & \multicolumn{2}{|c|}{ BCG-vaccinated group } & \multicolumn{2}{c}{ Non-vaccinated group } \\
\hline Examinees & Leprosy (\%) & Examinees & Leprosy (\%) \\
\hline Convit (Venezuela) & 584 & $5(0.86)$ & 522 & $29(5.56)$ \\
Fernandez (Argentina) & 28 & $9(32.1)$ & 55 & $23(41.8)$ \\
Chatterjee (India) & 678 & $5(0.74)$ & 1,651 & $283(17.14)$ \\
Yanagisawa (Japan) & 133 & $2(1.5)$ & 36 & $17(42.2)$ \\
Kinnear Brown (England) & 8,091 & $18(0.22)$ & 8,071 & $89(1.10)$ \\
\hline
\end{tabular}


B C G 接種を受けたものからのらい発病は 133 名中 2 名 (1.5\%) であったのに対し，ツ反応陰性でありながら B C G 接種を受けなかったものからのらい発病は36名中 17名(42.2\%)であって, B C G接種がらい発病阻止に効 果的であること示唆するものであった。また Convit, Fernandez, Chatterjee の成績も，BCG 接種者に和け るらい発病率が非接種者に抢けるそれよりも低いてとを 示していた。

しかし, 疫学的調查によってBCGの效果在調查子る 場合には,らい発病に関係のある M. leprae 感染以外 の宿主側の諸条件を考虑に入れなければならないので， その効果判定は極めてむずかしい己言えよう。最近 Kinnear Brown $ら^{8)}$ は Uganda の住民についてッ反応 陰性者执よび弱陽性者を二分し，一群にはＢＣＧ存接種 し, 他の群は B C G 索接種しない対照群として, 画群に おけるらい発病率を比較した。研究開始後 2 年半の間の らい発病率をみると, B C G接種者では 8,091 名中18名 (0.22\%)であったのに刘し B C G非接種者では 8,071 名中89名 (1.10\%) であって, 前者の発病率の方が低か った。その後さらに観察を続けた成績によると， B C G 接種者群での発病率は非接種者群におけるそれの7.5 分 の 1 にすぎず，明らかにBCG接種かららい発病阻止に有 効であるてとを示していた。また一方われわれが感作モ ルモットおよび一般住民について皮内反志の面から B C Gと M. leprae との関連性をしらべた成績 9,10$\rangle$ 亿扝 いても，M. leprae は結核菌よりもBCGにより多い類 似抗原を有しているてとが認められて扣り，抗原的にみ てもBCGがらい発病阻止について大きな役割老有して いることが示されていた。

さて1960年 Shepard1，2) がマウス足底部で M. leprae が発育可能であることを発見して以来，1965年われわれ もこれを確認しえたのでー 6)，らいに関する実験的研 究の緒口を開くことが出来た。るこで Shepard から分 与をうけた M. leprae のみでなく，われわれが日本の 患者加ら分離した M. leprae をす用いて，マウス底足 部組織内で発育する M. leprae 飞対する BCGの影響 について検討を加えた。まず BCG生菌或は加熱死菌の 生食水浮遊液を筋肉内に注射した免疫マウス, 更にB C G. 生菌或は死菌を Drackeol No. 6 (Adjuvant) 飞浮遊 したもの等肉内に注射した免疫マウスについて，足底 部に感染した M. leprae の增殖状態を非充疫対照マウ スの場合と比較した結果，或るときには M. leprae の 增殖贸制がみられたが，また或る場合にはをの增殖抑制 がみられなかった。そして，かかる成績はBCGの接種
時期とは余り関係のないものであった。证って，筋肉内 注射によってBCGで免疫した場合には，BCGの顕著 な M. leprae の增殖抑制效果老認めることは出来なか った。

実験的結核症に対する BCG の効果をしらべる場合 に，実験動物としてはマウスを用いるよりもモルモット を用いた方がより明確な成績を得ることが出来ること は，すでに諸家が認めていることである。しかしマウス を用いて検討しなければならない場合には，静脈内注射 によるBCGの免疫方法を用い, 静脈内注射によって感 染された結核菌のマウス臓器内に打ける増殖抑制を検討 亦る万法が一般に用いられている。従って，筋肉内注射 による免疫法よりあより強力にマウスを免疫しうる方法 について検討を加えた結果, $\mathrm{BCG}$ 生菌生食水浮遊液に 上万免疫は足庭部への皮下注射加或は静脈内注射がより 効果的であり，またBCGの生食水浮遊液による免疫よ りも Drackeol No. 6 の如き Adjuvant に浮遊したBC G生菌で免疫する方がより有效であることが明らかとな った。

らしの如き感染から発病までにかなりの年月を必要と する疾患では，BCGの免疫力持続期間を考慮すると， その接種時期が問題である。足底部皮下注射によって CG接種をうけたマウスにおける M. leprae の発育阻 止効果をみると，感染 1 力月前にB C G 接種を行なって も有効であった。また感染と同時或は感染後 1 〜 3 月 目に静脈内注射によってBCG接種を行なったマウス足 底部での M. leprae の発育阻止効果では, 感染と同時 或は感染後 1 力月目にBCGを接種したものにその効果 が認められた。従って，BCG接種の時期は M. leprae の増殖速度と B C G の免没持続期間加ら考えて, 感染 1 力月前から感染後 1 力月目までの間に行なうのが最適之 言えよう。われわれがマウスに扎て得たこれらの成績 から人体におけるらいを考えてみると，らいの潜伏期間 を考虑に入れて感染後 1 年以内にB C G 接種が行なわれ ているならば, 発病阻止効果在有することが推察され 万。

さて、マウスにおいて実験的に得た上述の如き B C G の M. leprae 增殖に対卞る阻止効果に関する成績㳘, Shepard が報告した成績 ${ }^{11,12)}$ とほぼ類似するもので あった。いずれの成績死ても，BCGの投与部位によ って成果差がみられ，またBCGのマウス足底内にお ける M. leprae 増殖阻止力は余り頻著なものではなか った。この原因は，1つは免疫力の多寒を感染局所の菌 数によって判定名ることによるあのと思われ，他の $1 つ$ 
はらいの場合に B C G免没を附与し難いマウスを実験動 物に用いなければならないことに由るものと推察され る。前者については他の細菌の場合について目下検討中 であるが，後者については今後動物において実験的らい 症とも言いうるような病变を全身化作りうる時がくるな らば解決されるものと考える。いずれる今後さらに検討 すべき課題であろう。

$$
\text { 結論 }
$$

マウス足底部組織内に打ける M. leprae の增殖代対 する B C G の影響について 検討を加え，次の成績をえ た。

1）BCGのマウスにおける兔疫の強さは，足底部皮下 注射法或は静脈内注射法によって附与するのが最む強力 であった。

2） B C G は生食水生菌浮遊液として使用するより屯 Adjuvant 加生菌浮遊液として用いた方がより強力な免 疫力を附与することが出来た。

3) B C G 接種の時期は感染 1 力月前加ら感染後 1 力月 目までの間に行なうのが最適であった。

以上の諸条件を考慮して行なった動物実験によると，

B C G はマウス足底部内に打ける M. leprae の增殖を 或る程度阻止するととが認められた。従って，一般住民 に招汁る没学的調査成績加ら得られた諸家の成績は動物 試験に扔いてい確認することが出来た。

（稿を終るにあたり，BCGを分与下された日本B C G 研究所川崎二郎博士飞深謝する)

\section{主 要 文 献}

1) Shepard, C. C. : The experimental disease that follows the injection of human leprosy bacilli into foot-pads of mice. J. Exper. Med. $112: 445-454$
(1960)

2) Shepard, C. C. : Multiplication of Mycobacterium leprae in the foot-pad of the mouse. Internat. J. Leprosy. $30: 291-306$ (1962)

3）丸山孝士：足踮に接種したらい菌に対するマウスの 組織反応の特徴, 国立多摩研究所研究業績集一創立 10 周年記念号, 37頁 (1965)

4 ) 中村一成・他 2 名: マウス足蹨への人らい菌接種, レプラ，35(2):111-112 (1966), 第 39 回日本㰋学 会総会

5）中村一成・他 2 名：マウス足底への人瀬菌接種，レ プラ, 36(2):86 (1967), 第40回日本癩学会総会

6) 前田道明・他 3 名：マウス足底部に抄けるM. leprae の増㽝，レプラ，投稿中

7) らい研究協議会：らい患者接触児童のらい発病に関 する疫学的観察, 日本医事新報, 1838号：6-13(1959)

8) Kinnear Brown et al. : BCG vaccination of children against leprosy : First reports of a trial in I'ganda.

Brit. Med. J. 1: 7-13 (1966)

9）前田道明, 中村一成：皮内反応からみたらい菌と B C G との関連性（第 1 報）感作モルモットに拉ける反 応, レプラ, 34:294-299 (1965)

10）前田道明・他 5 名：皮内反応加らみたらい菌と B C $\mathrm{G}$ 上の関連性（第 2 報）人体化拈引る反応の比較, レ プラ, $35: 1-7$ (1966)

11) Shepard, C. C. : Vaccination against experimental infection with Mycobacterium leprae. Amer. J. Epidemiology. $81: 150-163$ (1965)

12) Shepard, C. C. : Vaccination against human leprosy bacillus infection of mice: Protection by BCG given during the incubation period. J. Immunology. $96: 279-283$ (1966) 